\title{
c-fos Reduces Corticosterone-Mediated Effects on Neurotrophic Factor Expression in the Rat Hippocampal CA1 Region
}

\author{
A. C. Hansson, ${ }^{1,2}$ W. Sommer, ${ }^{2}$ R. Rimondini, ${ }^{2}$ B. Andbjer, ${ }^{2}$ I. Strömberg, ${ }^{1}$ and K. Fuxe ${ }^{1}$ \\ Departments of ${ }^{1}$ Neuroscience and ${ }^{2}$ NEUROTEC, Karolinska Institutet, 17177 Stockholm, Sweden
}

The transcription of neurotrophic factors, i.e., basic fibroblast growth factor $(b F G F)$ and brain-derived neurotrophic factor $(B D N F)$ is regulated by glucocorticoid receptor (GR) and mineralocorticoid receptor (MR) activation despite the lack of a classical glucocorticoid response element in their promoter region.

A time course for corticosterone $(10 \mathrm{mg} / \mathrm{kg}$, s.c.) in adrenalectomized rats revealed a peak hormone effect at the $4 \mathrm{hr}$ time interval for $b F G F$ ( $110-204 \%$ increase), $B D N F$ (53-67\% decrease), GR (53-64\% decrease), and $M R$ (34-56\% decrease) mRNA levels in all hippocampal subregions using in situ hybridization. c-fos mRNA levels were affected exclusively in the dentate gyrus after $50 \mathrm{~min}$ to $2 \mathrm{hr}(38-46 \%$ decrease).

Furthermore, it was evaluated whether corticosterone regulation of these genes depends on interactions with the transcription factor complex activator protein-1. c-fos antisense oligodeoxynucleotides were injected into the dorsal hippocampus of adrenalectomized rats. Corticosterone was given $2 \mathrm{hr}$ later, and the effects on gene expression were measured $4 \mathrm{hr}$ later. In CA1, antisense treatment significantly and selectively enhanced the hormone action on the expression of $b F G F$ ( $44 \%$ enhanced increase) and $B D N F$ ( $38 \%$ enhanced decrease) versus control oligodeoxynucleotide treatment. In addition, an upregulation of $c$-fos expression ( $89 \%$ increase) was found. There were no effects of $c$-fos antisense on hippocampal GR and $M R$ expression. Thus it seems that a tonic $c$-fos mechanism exists within CA1, which reduces $G R$ - and $M R$-mediated effects on expression of $b F G F$ and $B D N F$.

Key words: adrenalectomy; basic fibroblast growth factor; brain-derived growth factor; glucocorticoid receptor; mineralocorticoid receptor; immediate early gene; antisense oligodeoxynucleotides; in situ hybridization; rat brain

\section{Introduction}

The adrenal steroid hormone corticosterone (CORT) regulates transcription via activation of two types of corticosteroid receptors, namely the mineralocorticoid receptor [MR (or type I)] and the glucocorticoid receptor [GR (or type II)], which can act directly as transcription factors by binding to their common glucocorticoid response element (GRE) (Beato et al., 1995). However, although there are clearly documented CORT effects on transcription of a number of genes, among them $G R$ and $M R$ as well as basic fibroblast growth factor $(b F G F)$ and brain-derived neurotrophic factor (BDNF) (Barbany and Persson, 1992; Chao et al., 1998; Hansson et al., 2000), no classical GREs have been found within the promoter regions of these genes. Thus, GR and MR may also interact with other regulators of transcription either by competition for shared binding motifs (Diamond et al., 1990; Funder, 1993; Pearce and Yamamoto, 1993) or by protein-protein interactions with other transcription factors (Schüle et al.,

\footnotetext{
Received May 1, 2002; revised April 7, 2003; accepted April 11, 2003.

This work was supported by a grant from the Marianne and Marcus Wallenberg Foundation and by a grant from the Swedish Medical Research Council (04X-715). We are grateful to Ulla-Britt Finman for technical assistance.

Correspondence should be addressed to Dr. A. C. Hansson, Department of NEUROTEC, Karolinska Institutet, Huddinge University Hospital, M 57, S-141 86 Stockholm, Sweden. E-mail: anita.hansson@neuro.ki.se. Copyright $\odot 2003$ Society for Neuroscience $\quad$ 0270-6474/03/236013-10\$15.00/0
}

1990; Yang-Yen et al., 1990; König et al., 1992; Reichardt et al., 1998).

The GR and the transcription factor activator protein-1 (AP-1) complex appear to interact with each other via mechanisms both dependent on and independent from DNA binding (Diamond et al., 1990, Schüle et al., 1990; Yang-Yen et al., 1990; König et al., 1992). AP-1 complexes consisting of c-fos/c-jun or c-fos/junB heterodimers are transcriptionally highly active. Tissue culture experiments have shown a negative interaction of GR and AP- 1 complexes on the transcriptional activity of target genes (Diamond et al., 1990; Jonat et al., 1990; Lucibello et al., 1990), but such interactions have not been observed for MR (Pearce and Yamamoto, 1993; Pearce, 1994). However, the importance of $\mathrm{c}$-fos in the adrenal steroid hormone regulation in the brain has never been studied in vivo.

With use of the adrenalectomized (ADX) animal model, it has been shown recently by means of in situ hybridization that CORT affects neurotrophic factor gene mRNA levels in the dorsal hippocampus that are unique for each particular gene in a cellular and region-specific manner and therefore seem to be strongly context dependent (Hansson et al., 2000). Here we ask whether the pattern of CORT-induced gene expression of $b F G F$ and $B D N F$ in the hippocampal subregions may be the result, in part, of GR/MR or AP-1 interactions, or both. Toward this aim, the 
ADX rat was used; this allows an analysis of the effects of an exogenous hormonal stimulus without interference with the endocrine stress response of the animals. The time course of gene expression was analyzed in the dorsal hippocampus for the neurotrophic factors $b F G F$ and $B D N F$, for the corticosteroid receptors $G R$ and $M R$, and for $c$-fos, a highly active component of the AP-1 complex, in response to CORT treatment. $c$-fos antisense oligodeoxynucleotides (ODNs) were used as a tool to specifically study the impact of AP-1 on CORT-induced gene regulation in the dorsal hippocampus. The feasibility and specificity of the $c$-fos antisense approach has been demonstrated by a number of laboratories, including the present one (Sommer et al., 1993, 1996, 1998).

\section{Materials and Methods}

Animals and treatment. Male Sprague Dawley rats (Alab, Stockholm, Sweden), weighing 200-250 gm, were kept under a standard light/dark cycle (lights on at 6 A.M. and off at 6 P.M.) and constant room temperature $\left(23^{\circ} \mathrm{C}\right)$ and had ad libitum access to tap water and food pellets.

Rats were bilaterally adrenalectomized under halothane anesthesia. The ADX model used has been characterized recently by Hansson et al. (2000). After surgery the rats were given $0.9 \% \mathrm{NaCl}$ in the drinking water. Twenty-four hours after ADX rats were injected subcutaneously either with a single high dose of CORT $(10 \mathrm{mg} / \mathrm{kg}$, s.c.; ADX + CORT group; $n=5$ ), which gives rise to full MR and GR occupation, or with a single injection of hormone vehicle (propylene glycol) alone (ADX + vehicle group; $n=5$ ). All surgical procedures and hormone injections (injection volume $1 \mathrm{ml} / \mathrm{kg}$ ) were performed between 7:00 and 9:00 A.M. Animals were anesthetized with sodium pentobarbital (Membumal; $100 \mathrm{mg} / \mathrm{kg}$ ) $50 \mathrm{~min}$ and 2, 4, 8, and $24 \mathrm{hr}$ after hormone or vehicle injection and were intracardially perfused with $100 \mathrm{ml}$ ice-cold saline after blood samples for serum CORT had been collected by cardiac puncture. In another control experiment, non-injected and vehicle-injected ADX animals were killed after $50 \mathrm{~min}$ and 4 and $24 \mathrm{hr}$ ( $n=4$ per time and treatment).

Using the same ADX animal model, a 15-mer partially phosphorothioated antisense ODN to $c$-fos (5'- GAA CAT CATT GGT $\underline{\text { CGT }}-3^{\prime}, 1$ nmol in $1 \mu \mathrm{l}$ of Ringer's solution, as $c$-fos oligo group; $n=6$ ) or a

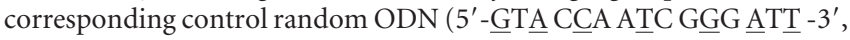
as control oligo group; $n=6$ ) was injected in a second experiment via a previously unilaterally implanted cannula guide into the dorsal hippocampus [ $1 \mu$ l over $2 \mathrm{~min}$; bregma anterior (A) $-3.3 \mathrm{~mm}$, lateral (L) $+2.7 \mathrm{~mm}$, ventral $(\mathrm{V})-4.3 \mathrm{~mm}$, according to the atlas of Paxinos and Watson (1982)]. Two hours later a single dose of CORT was given (10 $\mathrm{mg} / \mathrm{kg}$ in propylene glycol, s.c.). After four hours the animals were anesthetized with sodium pentobarbital and intracardially perfused with 100 $\mathrm{ml}$ ice-cold saline after blood samples for serum CORT had been collected by cardiac puncture. After the rats were killed, brains were rapidly removed, frozen in liquid isopentane $\left(-40^{\circ} \mathrm{C}\right)$, and stored at $-70^{\circ} \mathrm{C}$. Coronal sections $(10 \mu \mathrm{m})$ were taken at bregma levels close to the cannula guide and at bregma level -4 to $-4.5 \mathrm{~mm}$ and mounted on slides (ProbeOn slides, Fischer/Biotech, Hampton, NH).

In a third experiment animals were unilaterally intrahippocampally injected with end-labeled $\left[\mathrm{S}^{35}\right] \gamma \mathrm{ATP}$ antisense $c$-fos ODN ( $1 \mu$ l over 1 min; bregma A $-3.3 \mathrm{~mm}, \mathrm{~L}+2.7 \mathrm{~mm}, \mathrm{~V}-4.3 \mathrm{~mm})$, and rats were killed by decapitation after $1 \mathrm{hr}(n=4)$ and $6 \mathrm{hr}(n=4)$. Transversal sections $(10 \mu \mathrm{m})$ were taken through the injection site, exposed for 2 and $7 \mathrm{~d}$ to $\beta$-Max Hyperfilm (Amersham Biosciences, Arlington Heights, IL), and counterstained with cresyl violet.

The animal experiments were approved by the local ethical committee (Stockholm Norra Försöksdjurs Etiska Kommittee).

Radioimmunoassay for corticosterone. Cardiac blood samples were collected in EDTA-containing tubes and centrifuged at $4 \times g$ for $20 \mathrm{~min}$ at $4^{\circ} \mathrm{C}$. Serum CORT levels were determined by radioimmunoassay (RIA) (Coat-a-count, Diagnostic Products Corporation, Los Angeles, CA). The RIA was performed with rat $\left[{ }^{125} \mathrm{I}\right] \mathrm{CORT}$. The CORT assay had a detection limit of $\sim 5.7 \mathrm{ng} / \mathrm{ml}$.

RNA probe synthesis. The bFGF riboprobes, both antisense and sense, were synthesized from a SmaI-XhoI fragment from rat cDNA (position: 525-1004 bp corresponding to the coding region for the mature protein) in Bluescript/SK ${ }^{+}$(Stratagene, San Diego, CA). The BDNF riboprobes (antisense and sense) were generated from a $350 \mathrm{bp} P v u \mathrm{II}-P s t \mathrm{I}$ fragment from rat cDNA, coding for a corresponding protein, and subcloned into the Bluescript/SK ${ }^{+}$plasmid. A $513 \mathrm{bp}$ EcoRI fragment from the $5^{\prime}$ end of the rat MR cDNA was subcloned into the vector pGEM4 (Promega, Madison, WI) and used for antisense and sense riboprobe generation. For the generation of the GR riboprobes (antisense and sense), we used a $673 \mathrm{bp}$ EcoRI-PstI rat GR cDNA fragment (position: 1691-2364 bp, corresponding to the 3 'portion of the coding region), subcloned into the vector pSP64 (Promega). The $c$-fos riboprobe was a 557 bp BglII-StuI fragment from rat cDNA in Bluescript $\mathrm{KS} \mathrm{II}^{+}$(Stratagene).

Antisense and sense RNA probes were synthesized from a $1 \mu \mathrm{g}$ linearized DNA template, incubated with transcription buffer ( $40 \mathrm{~mm}$ Tris$\mathrm{HCl}, \mathrm{pH} 7.5,6 \mathrm{mM} \mathrm{MgCl}_{2}, 2 \mathrm{~mm}$ spermidine) in the presence of $12.5 \mathrm{nmol}$ ATP, CTP, GTP, 500 pmol UTP, and 125 pmol $\left[\alpha-{ }^{35}\right.$ S UTP $(1350 \mathrm{Ci} /$ mmol; NEN/DuPont, Boston, MA), 1 U RNase inhibitor, and 1 U RNA polymerase (Roche Molecular Biochemicals, Bromma, Sweden) at $37^{\circ} \mathrm{C}$ for $1 \mathrm{hr}$. The DNA was removed by digestion with RNase-free DNase at $37^{\circ} \mathrm{C}$ for $15 \mathrm{~min}$. The transcripts were purified using spin columns (Amersham Biosciences), and the quality of the riboprobes was analyzed on a $8 \mathrm{M}$ urea/5\% polyacrylamide gel (PAGE).

End-labeling of oligodeoxynucleotides. Radioactive labeling of phosphorothioate-modified antisense $c$-fos ODN was made by endlabeling with $\left[\mathrm{S}^{35}\right] \mathrm{ATP} \gamma \mathrm{S}$ and $\mathrm{T} 4$ polynucleotide kinase, followed by PAGE for purification. Aliquots of $5 \times 10^{5} \mathrm{dpm}$ were dried under vacuum and then mixed for injection with $1 \mathrm{nmol}$ of cold ODN. The ODN mix was infused at $1 \mathrm{~mm}$ concentration in Ringer's solution.

In situ hybridization. The sections mounted on slides were brought to room temperature and fixed for $15 \mathrm{~min}$ in $4 \%$ paraformaldehyde in PBS, $\mathrm{pH}$ 7.0. After fixation the slides were washed in PBS, $\mathrm{pH}$ 7.4, for $10 \mathrm{~min}$ and rinsed two times in sterilized water for $5 \mathrm{~min}$, each followed by a deproteination of the tissue with $0.1 \mathrm{M} \mathrm{HCl}$ for $10 \mathrm{~min}$. The slides were rinsed twice in PBS, pH 7.4, for 5 min and were acetylated in $0.1 \mathrm{M}$ triethanolamine, $\mathrm{pH} 8.0 / 0.25 \%$ acetic anhydride for $20 \mathrm{~min}$, washed again twice in PBS, pH 7.4, for 5 min, dehydrated in graded ethanol, and air dried. The slides were prehybridized in a humidified chamber with prehybridization buffer [ $50 \%$ deionized formamide, $50 \mathrm{~mm}$ Tris- $\mathrm{HCl}$, pH 7.6, 25 mм EDTA, pH 8.0, 20 mu NaCl, 0.25 mg/ml yeast tRNA, $2.5 \times$ Denhardt's solution (0.05\% Ficoll, $0.05 \%$ polyvinylpyrrolidone, $0.05 \%$ bovine serum albumin)] at $37^{\circ} \mathrm{C}$ for $2-3 \mathrm{hr}$. After the prehybridization buffer was drained off the slides, the sections were hybridized with $80 \mu \mathrm{l}$ hybridization buffer ( $50 \%$ deionized formamide, $20 \mathrm{~mm}$ Tris- $\mathrm{HCl}, \mathrm{pH}$ 7.6, 1 mм EDTA, pH 8.0, 0.3 M NaCl, 0.2 M DTT, $0.5 \mathrm{mg} / \mathrm{ml}$ yeast tRNA, $0.1 \mathrm{mg} / \mathrm{ml}$ poly-A-RNA, $1 \times$ Denhardt's solution, $10 \%$ dextransulfate) containing $0.5-1 \times 10^{6} \mathrm{cpm}$ of either the labeled antisense RNA or sense RNA. The sections were covered with siliconized coverslips and incubated at $44^{\circ} \mathrm{C}$ for $18 \mathrm{hr}$ in a humidified chamber. After hybridization, the coverslips were removed by washing with $1 \times$ standard saline citrate (SSC) at $48^{\circ} \mathrm{C}$ for $30 \mathrm{~min}$, followed by washing twice in $0.5 \times \mathrm{SSC} / 50 \%$ formamide at $48^{\circ} \mathrm{C}$ for $30 \mathrm{~min}$. After two additional washings in $1 \times \mathrm{SSC}$ for $15 \mathrm{~min}$ at $48^{\circ} \mathrm{C}$, the sections were treated with $1 \mu \mathrm{g} / \mathrm{ml}$ RNAaseA in $0.5 \mathrm{~m} \mathrm{NaCl}, 10 \mathrm{~mm}$ Tris-HCl, $5 \mathrm{~mm}$ EDTA, $\mathrm{pH} 8.0$, for $45 \mathrm{~min}$ at $37^{\circ} \mathrm{C}$. After two washing steps in $1 \times$ SSC for $20 \mathrm{~min}$ at $55^{\circ} \mathrm{C}$ followed by a washing in $1 \times$ SSC for $15 \mathrm{~min}$ at room temperature, the slides were dehydrated in graded ethanol and air dried. The hybridized sections were exposed for 1-4 weeks to $\beta$-Max Hyperfilm (Amersham Biosciences). A few sections of each animal from the second experiment were counterstained with cresyl violet for control of cannula guide placement.

Double labeling of c-fos transcripts and glial fibrillary acidic protein immunoreactivity. After in situ hybridization with $\mathrm{S}^{35}$-labeled $c$-fos ribo-

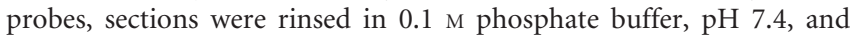
incubated with the primary antibody [glial fibrillary acidic protein (GFAP), monoclonal mouse anti-GFAP, 1:200; Chemicon International, Harrow, UK] for $48 \mathrm{hr}$ at $4^{\circ} \mathrm{C}$. The antibodies were diluted in $0.1 \mathrm{M}$ phosphate buffer with $0.3 \%$ Triton X-100 (Sigma, St. Louis, MO), and all incubations were performed in humidified chambers. The sections were rinsed in $0.1 \mathrm{M}$ phosphate buffer, and the secondary antibody (biotinyl- 
ated horse anti-mouse, 1:100; Vector Laboratories, Burlingame, CA) was applied and incubated for $2 \mathrm{hr}$ at room temperature. After rinsing the sections were incubated with solutions $A$ and B in $0.1 \mathrm{M}$ phosphate buffer (1:100; Vectastain ABC Reagent, Vector Laboratories) for $1 \mathrm{hr}$ at room temperature. The sections were then exposed to $0.05 \mathrm{M}$ Trizma buffer, $\mathrm{pH}$ 7.1, and reacted with $3,3^{\prime}$ diaminobenzidine tetrahydrochloride as a chromogen. The reaction was stopped by a $\mathrm{pH}$ shift in $0.05 \mathrm{~m}$ Trizma, $\mathrm{pH}$ 8.5. Sections were dehydrated in graded ethanol, coated with film emulsion (Ilford, Cheshire, UK), and stored in desiccated light-tight boxes at $4^{\circ} \mathrm{C}$ for 4 weeks. After development the sections were counterstained with cresyl violet and coverslipped with Mountex (Göteborgs Termometerfabrik). Sections were digitized and evaluated using a Leica microscope connected with a high-resolution digital CCD video camera.

Double immunofluorescence staining. Sections were brought to room temperature, rehydrated, rinsed in $0.01 \mathrm{M}$ phosphate buffer, and incubated with a mixture of two primary antibodies [polyclonal rabbit antic-fos antibody (Ab-5; Oncogene Research Products, San Diego, CA; 1:300) and either monoclonal mouse anti-GR antibody, a generous gift from Dr. A.-C. Wikström, Karolinska Institutet (Okret et al., 1984), 1:200, or a monoclonal mouse anti-neuronal nuclei antibody (NeuN; Chemicon, Temecula, CA; 1:200) or monoclonal mouse anti-GFAP (Chemicon; 1:200)] for $48-72 \mathrm{hr}$ at $4^{\circ} \mathrm{C}$. The sections were rinsed in 0.01 $\mathrm{M}$ phosphate buffer, and a mixture of the two secondary antibodies [biotinylated donkey anti-rabbit antibody (Amersham Biosciences; 1:50) and sheep anti-mouse-fluorescein isothiocyanate (FITC)-linked antibody (Amersham Biosciences; 1:20)] were added and incubated for 1-2 $\mathrm{hr}$ at room temperature. Sections were rinsed again and exposed to streptavidin-Texas Red (Amersham Biosciences; 1:100). Sections were rinsed briefly, mounted in a mounting medium for fluorescent signals (Dako, Carpinteria, CA), and coverslipped. The sections were evaluated by using a Zeiss Axiophot II microscope equipped with epiluminescence (mercury lamp) and filter sets (excitation/emission: FITC, 490/525 nm; Texas Red, 590/620 nm). The fluorescence microscope was connected to a high-resolution digital CCD video camera and a computer with OpenLab software.

Data analysis. Semiquantitative values of the mRNA levels were obtained by measuring the gray values of the film autoradiograms as illustrated in Figures 3 and 4 using an SAS Biovision image analyzing system (Avanzati, Milan, Italy). Radioactivity artifacts on autoradiograms close to tissue damage were carefully excluded in all measurements. Three measurements were performed for each region: (1) the total value, i.e., measurements of the region in the sections hybridized with $\left[\alpha-{ }^{35}\right.$ S $]$ UTP-labeled antisense RNA; (2) the unspecific value, i.e., measurements of the corresponding region in the control sections hybridized with $\left[\alpha{ }^{-35}\right.$ S UTP-labeled sense RNA; (3) the background value, i.e., measurements of the film background outside the sections. The transmittance percentage values (T\%) of specific and unspecific labeling were obtained as described in Benfenati et al. (1986) and Zoli et al. (1991). From the T\% values the optical density (O.D.) can be obtained (O.D. = $-\log \mathrm{T} \%)$. The data were expressed as optical density (means \pm SEM). Two-way ANOVA for treatment and time followed by Fisher's PLSD post hoc test and Bonferroni's correction (Fisher's $p$ value $\times$ number of brain regions analyzed; ${ }^{*} p<0.05 ;{ }^{* *} p<0.01 ;{ }^{* *} p<0.001$ ) was used for the statistical analysis in the time course experiment. One-way ANOVA followed by Bonferroni's correction ( $p$ value $\times$ number of brain regions analyzed; $\left.{ }^{*} p<0.05 ;{ }^{* *} p<0.01\right)$ was used to analyze the treatment effect in the antisense $c$-fos experiment.

\section{Results}

\section{Radioimmunoassay for corticosterone serum levels}

After a single subcutaneous injection of CORT $(10 \mathrm{mg} / \mathrm{kg})$ to ADX rats, the serum levels of CORT were determined at the time of killing. Serum CORT levels were high after $50 \mathrm{~min}(2545 \pm 321$ ng CORT $/ \mathrm{ml}$ blood serum; mean \pm SEM; $n=5)$ and then gradually declined over the $2 \mathrm{hr}(805 \pm 143 \mathrm{ng} \mathrm{CORT} / \mathrm{ml} ; n=5), 4 \mathrm{hr}$ $(147 \pm 27 \mathrm{ng}$ CORT $/ \mathrm{ml} ; n=5)$, and $8 \mathrm{hr}$ time interval ( $29 \pm 4 \mathrm{ng}$ $\mathrm{CORT} / \mathrm{ml} ; n=5$ ) down to undetectable serum CORT levels $24 \mathrm{hr}$ after the injection. In all vehicle-injected ADX rats, serum levels of CORT were undetectable in each time interval analyzed.

In the second experiment, CORT ( $10 \mathrm{mg} / \mathrm{kg}$, s.c.) was injected $2 \mathrm{hr}$ after antisense $c$-fos or control ODN treatment in $24 \mathrm{hr}$ ADX rats. Four hours later, serum CORT levels did not differ between the $c$-fos oligo group ( $275 \pm 80 \mathrm{ng} \mathrm{CORT} / \mathrm{ml}$ serum $)$ and the control oligo animal group (372 $\pm 65 \mathrm{ng} \mathrm{CORT} / \mathrm{ml}$ serum; oneway ANOVA: $F_{(1,10)}=0.89$; not significant).

\section{Effects of corticosterone treatment on gene expression in the dorsal hippocampus}

In situ hybridization analysis was performed for $b F G F, B D N F$, $G R, M R$, and $c$-fos mRNAs. Optical density values from the dorsal hippocampus were obtained from autoradiograms, and the data were analyzed either by two-way ANOVA in the CORT time course experiment or by one-way ANOVA in the as $c$-fos experiment, followed by Bonferroni's correction. The optical density data and the results of the post hoc analysis are summarized in Tables 1-3. To better demonstrate the most important actions of CORT on gene expression levels, the optical density values were transformed into relative changes (\%) in relation to the ADX + vehicle-treated group in Figure 1. Figure $3 d$ shows the effects of CORT on gene expression levels after $c$-fos blockade as relative changes (percentage) in relation to control ODN-injected ADX rats. The distribution patterns for $b F G F, B D N F, G R$, and $M R$ mRNA levels in the dorsal hippocampus are shown in Figure 2 and are similar to those described in Hansson et al. (2000). In situ hybridization of $c$-fos mRNA showed a moderate and low expression pattern in CA1 to CA4 and DG, respectively (see Fig. 2).

\section{Time course of gene expression after corticosterone treatment \\ bFGF}

bFGF mRNA levels were significantly and time-dependently increased after acute CORT treatment in all hippocampal subregions as shown by two-way ANOVA for treatment $\left(\mathrm{CA} 1: F_{(1,40)}=132.3, p<0.0001\right.$; CA2: $F_{(1,40)}=70.1, p<$ 0.0001; CA3: $F_{(1,40)}=148.9, p<0.0001 ; \mathrm{DG}: F_{(1,40)}=123.6$, $p<0.0001)$ and interaction of treatment and time (CA1: $F_{(1,40)}=$ $18.7, p<0.0001 ; \mathrm{CA} 2: F_{(1,40)}=7.7, p=0.0001 ; \mathrm{CA} 3: F_{(1,40)}=28.6$, $p<0.0001$; DG: $\left.F_{(1,40)}=46, p<0.0001\right)$. Bonferroni's corrected post hoc analysis revealed that CORT induced strong and significant increases of bFGF mRNA levels in all hippocampal subfields between 2 and $8 \mathrm{hr}$ after treatment (CA1: 90 to 119\%, CA2: 110 to 146\%, CA3: 85 to 157\%, DG: 84 to 204\%) (Table 1, Figs. 1, 2). Only in CA2 did CORT induce long-lasting changes of bFGF mRNA levels observed even after $24 \mathrm{hr}$ (105\% increase) (Table 1). Levels of $b F G F$ mRNAs were not changed in vehicle-treated ADX rats over the time course of the experiment in all analyzed subregions.

\section{BDNF}

CORT induced time-dependent significant changes of BDNF mRNA levels as revealed by two-way ANOVA for treatment $\left(\mathrm{CA} 1: F_{(1,39)}=38, p<0.0001 ; \mathrm{CA} 3: F_{(1,39)}=12.1, p=0.0013\right.$; DG: $\left.F_{(1,39)}=108, p<0.0001\right)$ and interaction of treatment and time $\left(\mathrm{CA} 1: F_{(1,39)}=2.9, p=0.03\right.$; CA3: $F_{(1,39)}=0.8$, not significant; DG: $\left.F_{(1,39)}=14.7, p<0.0001\right)$. The corrected post hoc test suggested a CORT-induced decrease of BDNF mRNA levels after 2-8 hr treatment in CA1 (30 to 53\%) and DG (44 to 67\%) (Table 1, Figs. 1, 2). In CA3, levels of BDNF mRNA were only significantly decreased after $2 \mathrm{hr}(26 \%)$ (Table 1, Fig. 1). BDNF mRNA 
Table 1. Effects of corticosterone ( $10 \mathrm{mg} / \mathrm{kg}$, s.c.) on gene expression levels in the dorsal hippocampus of ADX rats

\begin{tabular}{|c|c|c|c|c|c|}
\hline & Time & CA1 & CA2 & CA3 & DG \\
\hline \multicolumn{6}{|l|}{$b F G F m R N A$} \\
\hline ADX + vehicle & $50 \mathrm{~min}$ & $125 \pm 4$ & $405 \pm 101$ & $148 \pm 8$ & $150 \pm 4$ \\
\hline $\mathrm{ADX}+\mathrm{CORT}$ & $50 \mathrm{~min}$ & $140 \pm 6$ & $340 \pm 21$ & $144 \pm 13$ & $164 \pm 9$ \\
\hline ADX + vehicle & $2 \mathrm{hr}$ & $119 \pm 5$ & $281 \pm 14$ & $130 \pm 5$ & $153 \pm 4$ \\
\hline $\mathrm{ADX}+\mathrm{CORT}$ & $2 \mathrm{hr}$ & $226 \pm 9^{* * *}$ & $652 \pm 52^{* * *}$ & $240 \pm 13^{* * *}$ & $336 \pm 17^{* * *}$ \\
\hline ADX + vehicle & $4 \mathrm{hr}$ & $125 \pm 16$ & $390 \pm 62$ & $118 \pm 9$ & $149 \pm 10$ \\
\hline $\mathrm{ADX}+\mathrm{CORT}$ & $4 \mathrm{hr}$ & $274 \pm 18^{* * *}$ & $818 \pm 48^{* * *}$ & $303 \pm 16^{* * *}$ & $453 \pm 28^{* * *}$ \\
\hline ADX + vehicle & $8 \mathrm{hr}$ & $95 \pm 4$ & $361 \pm 115$ & $107 \pm 11$ & $130 \pm 7$ \\
\hline $\mathrm{ADX}+\mathrm{CORT}$ & $8 \mathrm{hr}$ & $205 \pm 17^{* * *}$ & $888 \pm 14^{* * *}$ & $269 \pm 20^{* * *}$ & $239 \pm 23^{* * *}$ \\
\hline ADX + vehicle & $24 \mathrm{hr}$ & $117 \pm 4$ & $257 \pm 12$ & $126 \pm 1$ & $157 \pm 3$ \\
\hline $\mathrm{ADX}+\mathrm{CORT}$ & $24 \mathrm{hr}$ & $119 \pm 5$ & $528 \pm 13^{* *}$ & $126 \pm 10$ & $130 \pm 3$ \\
\hline \multicolumn{6}{|l|}{ BDNF mRNA } \\
\hline ADX + vehicle & $50 \mathrm{~min}$ & $158 \pm 12$ & n.e. & $600 \pm 44$ & $331 \pm 33$ \\
\hline ADX + CORT & $50 \mathrm{~min}$ & $144 \pm 15$ & n.e. & $588 \pm 31$ & $284 \pm 17$ \\
\hline ADX + vehicle & $2 \mathrm{hr}$ & $141 \pm 7$ & n.e. & $666 \pm 42$ & $317 \pm 20$ \\
\hline ADX + CORT & $2 \mathrm{hr}$ & $98 \pm 14^{*}$ & n.e. & $490 \pm 51^{*}$ & $138 \pm 10^{* * *}$ \\
\hline ADX + vehicle & $4 \mathrm{hr}$ & $133 \pm 3$ & n.e. & $592 \pm 46$ & $340 \pm 17$ \\
\hline $\mathrm{ADX}+\mathrm{CORT}$ & $4 \mathrm{hr}$ & $63 \pm 5^{* * *}$ & n.e. & $500 \pm 31$ & $112 \pm 13^{* * *}$ \\
\hline ADX + vehicle & $8 \mathrm{hr}$ & $136 \pm 15$ & n.e. & $545 \pm 49$ & $362 \pm 23$ \\
\hline ADX + CORT & $8 \mathrm{hr}$ & $79 \pm 3^{* * * *}$ & n.e. & $434 \pm 25$ & $203 \pm 14^{* * *}$ \\
\hline ADX + vehicle & $24 \mathrm{hr}$ & $138 \pm 12$ & n.e. & $599 \pm 68$ & $251 \pm 7$ \\
\hline $\mathrm{ADX}+\mathrm{CORT}$ & $24 \mathrm{hr}$ & $122 \pm 8$ & n.e. & $493 \pm 42$ & $261 \pm 15$ \\
\hline \multicolumn{6}{|l|}{ GR mRNA } \\
\hline ADX + vehicle & $50 \mathrm{~min}$ & $359 \pm 13$ & $373 \pm 28$ & $107 \pm 5$ & $211 \pm 8$ \\
\hline ADX + CORT & $50 \mathrm{~min}$ & $324 \pm 25$ & $316 \pm 10$ & $106 \pm 9$ & $186 \pm 15$ \\
\hline ADX + vehicle & $2 \mathrm{hr}$ & $379 \pm 18$ & $353 \pm 18$ & $121 \pm 7$ & $230 \pm 13$ \\
\hline ADX + CORT & $2 \mathrm{hr}$ & $179 \pm 14^{* * *}$ & $166 \pm 23^{* * *}$ & $63 \pm 9^{* * *}$ & $87 \pm 1^{* * *}$ \\
\hline ADX + vehicle & $4 \mathrm{hr}$ & $343 \pm 21$ & $288 \pm 15$ & $104 \pm 14$ & $230 \pm 13$ \\
\hline ADX + CORT & $4 \mathrm{hr}$ & $122 \pm 5^{* * * *}$ & $104 \pm 10^{* * *}$ & $39 \pm 12^{* * *}$ & $109 \pm 5^{* * * *}$ \\
\hline ADX + vehicle & $8 \mathrm{hr}$ & $341 \pm 41$ & $318 \pm 40$ & $128 \pm 16$ & $236 \pm 15$ \\
\hline ADX + CORT & $8 \mathrm{hr}$ & $164 \pm 6^{* * *}$ & $159 \pm 9^{* * *}$ & $48 \pm 6^{* * *}$ & $167 \pm 9^{* * *}$ \\
\hline ADX + vehicle & $24 \mathrm{hr}$ & $409 \pm 12$ & $367 \pm 13$ & $128 \pm 9$ & $248 \pm 15$ \\
\hline $\mathrm{ADX}+\mathrm{CORT}$ & $24 \mathrm{hr}$ & $266 \pm 16^{* * *}$ & $249 \pm 21^{* * *}$ & $77 \pm 5^{* *}$ & $192 \pm 7^{* *}$ \\
\hline \multicolumn{6}{|l|}{ MR mRNA } \\
\hline ADX + vehicle & $50 \mathrm{~min}$ & $496 \pm 37$ & $848 \pm 61$ & $496 \pm 40$ & $414 \pm 25$ \\
\hline ADX + CORT & $50 \mathrm{~min}$ & $538 \pm 31$ & $940 \pm 69$ & $602 \pm 9^{*}$ & $451 \pm 18$ \\
\hline ADX + vehicle & $2 \mathrm{hr}$ & $523 \pm 23$ & $944 \pm 54$ & $551 \pm 29$ & $420 \pm 9$ \\
\hline ADX + CORT & $2 \mathrm{hr}$ & $384 \pm 32^{*}$ & $747 \pm 46$ & $459 \pm 21$ & $352 \pm 24$ \\
\hline ADX + vehicle & $4 \mathrm{hr}$ & $407 \pm 16$ & $769 \pm 17$ & $466 \pm 34$ & $379 \pm 6$ \\
\hline ADX + CORT & $4 \mathrm{hr}$ & $249 \pm 36^{* *}$ & $607 \pm 87$ & $306 \pm 35^{* * *}$ & $168 \pm 15^{* * *}$ \\
\hline ADX + vehicle & $8 \mathrm{hr}$ & $405 \pm 31$ & $728 \pm 51$ & $549 \pm 69$ & $363 \pm 27$ \\
\hline ADX + CORT & $8 \mathrm{hr}$ & $295 \pm 19$ & $550 \pm 23$ & $335 \pm 27^{* * *}$ & $250 \pm 21^{* * *}$ \\
\hline ADX + vehicle & $24 \mathrm{hr}$ & $455 \pm 45$ & $809 \pm 54$ & $606 \pm 48$ & $382 \pm 18$ \\
\hline ADX + CORT & $24 \mathrm{hr}$ & $359 \pm 23$ & $701 \pm 34$ & $343 \pm 25^{* * *}$ & $345 \pm 9$ \\
\hline \multicolumn{6}{|l|}{ c-fos mRNA } \\
\hline ADX + vehicle & $50 \mathrm{~min}$ & $107 \pm 10$ & n.e. & $134 \pm 7$ & $92 \pm 5$ \\
\hline ADX + CORT & $50 \mathrm{~min}$ & $85 \pm 10$ & n.e. & $120 \pm 12$ & $57 \pm 7^{*}$ \\
\hline ADX + vehicle & $2 \mathrm{hr}$ & $41 \pm 4$ & n.e. & $102 \pm 6$ & $56 \pm 4$ \\
\hline ADX + CORT & $2 \mathrm{hr}$ & $31 \pm 7$ & n.e. & $78 \pm 8$ & $30 \pm 3^{*}$ \\
\hline ADX + vehicle & $4 \mathrm{hr}$ & $39 \pm 8$ & n.e. & $62 \pm 8$ & $40 \pm 5$ \\
\hline $\mathrm{ADX}+\mathrm{CORT}$ & $4 \mathrm{hr}$ & $24 \pm 3$ & n.e. & $56 \pm 4$ & $34 \pm 3$ \\
\hline ADX + vehicle & $8 \mathrm{hr}$ & $47 \pm 7$ & n.e. & $69 \pm 14$ & $45 \pm 7$ \\
\hline ADX + CORT & $8 \mathrm{hr}$ & $50 \pm 6$ & n.e. & $69 \pm 3$ & $42 \pm 6$ \\
\hline ADX + vehicle & $24 \mathrm{hr}$ & $48 \pm 3$ & n.e. & $82 \pm 14$ & $48 \pm 6$ \\
\hline $\mathrm{ADX}+\mathrm{CORT}$ & $24 \mathrm{hr}$ & $48 \pm 7$ & n.e. & $73 \pm 8$ & $35 \pm 6$ \\
\hline
\end{tabular}

$>$ Data are expressed as optical densities $\left(\times 10^{3}\right.$, means \pm SEM); n.e. $=$ not evaluated. Analysis at Bregma levels -3 to -4 mm were performed by two-way ANOVA (treatment $\times$ time) followed by Fisher's PLSD test and Bonferroni's correction. Significances between mRNA levels are shown between corticosterone-treated (ADX + C CRT) and hormone vehicle-treated (ADX + vehicle) ADX rats at the same time point. ${ }^{*} p<0.05$, ${ }^{* *} p<0.01,{ }^{* * *} p<0.001 ; n=5$ per group.

levels were not changed in vehicle-treated ADX rats during the time course in all subregions analyzed.

GR

A significant time-dependent decrease of $G R$ mRNA levels by CORT was found in all hippocampal subregions using two-way ANOVA for treatment $\left(\mathrm{CA} 1: F_{(1,39)}=149.2, p<0.0001\right.$; CA2:
$F_{(1,39)}=116.2, p<0.0001 ;$ CA3: $F_{(1,39)}=62.7, p<0.0001 ;$ DG: $\left.F_{(1,39)}=130.6, p<0.0001\right)$ and interaction of treatment and time $\left(\mathrm{CA} 1: F_{(1,39)}=6.2, p=0.0006 ; \mathrm{CA} 2: F_{(1,39)}=3.3, p=0.0194\right.$; CA3: $F_{(1,39)}=4.0, p=0.0085$; DG: $\left.F_{(1,39)}=8.8, p<0.0001\right)$. Corrected post hoc analysis revealed strong and significant longlasting decreases of GR mRNA levels from 2 to $24 \mathrm{hr}$ (CA1: 35 to 
CA1
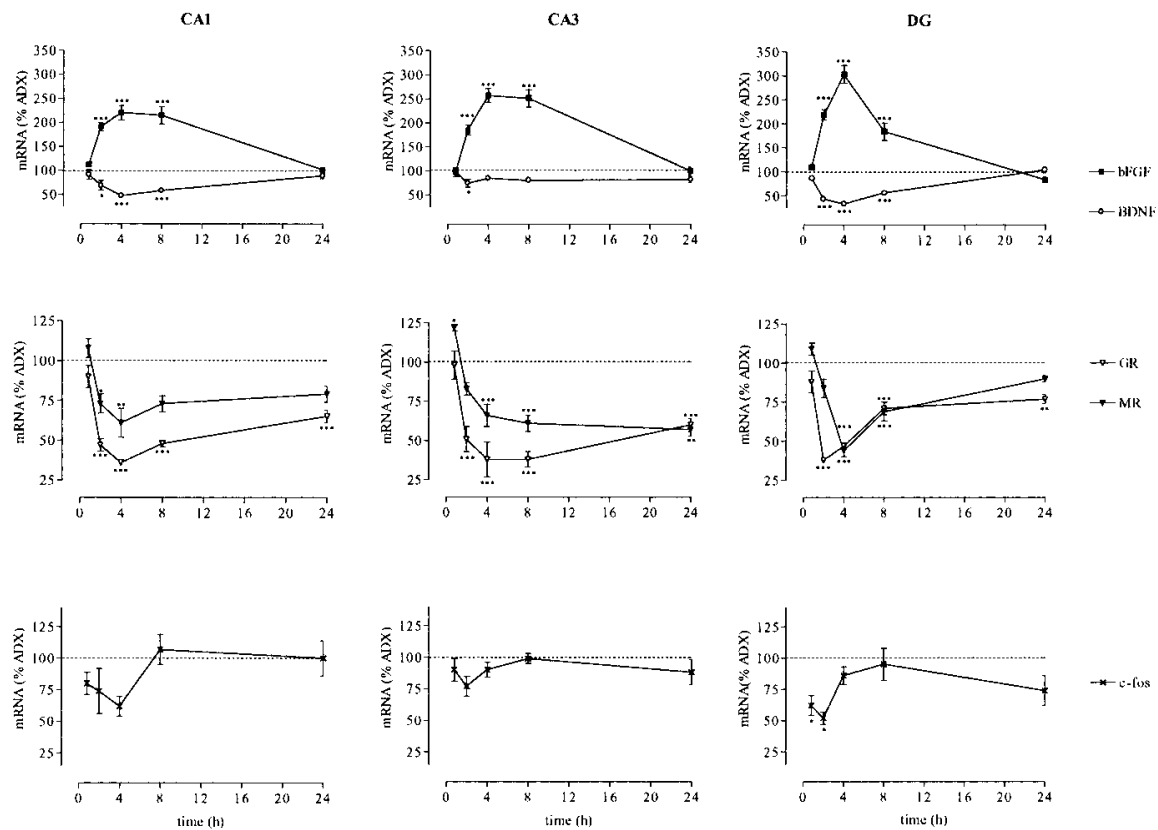

Figure 1. Densitometric evaluation of in situ hybridization from autoradiograms. Values are given in percentage of the ADX group (mean $\pm \mathrm{SEM} ; n=5$ ) versus vehicle-treated control ADX rats. Statistical analysis was performed by two-way ANOVA (treatment $\times$ time) followed by Fisher's PLSD test and Bonferroni's correction. ${ }^{*} p<0.05,{ }^{* *} p<0.01,{ }^{* * *} p<0.001$ versus ADX group. CA1, CA3, Cornus Ammon areas; DG, dentate gyrus. For details on treatment, see Materials and Methods. in $c$-fos mRNA levels at $50 \mathrm{~min}$ in both vehicle- and CORT-treated rats compared with the other time points in CA1 (2-24 hr: 123 to $245 \%$ increase), CA3 (4-24 hr: 63 to $116 \%$ increase), and DG (2-24 hr: 64 to $130 \%$ increase) (Table 1).

There was a decrease in $c$-fos mRNA levels by $27 \%$ in vehicle injected versus non-injected ADX rats at $50 \mathrm{~min}$ in DG (two-way ANOVA for treatment and time: $F_{(2,14)}=6.0, p<0.0133$ ) (Table 2). There were no significant differences in $c$-fos mRNA levels between injected and non-injected ADX rats in CA1 and CA 3 at any time interval (Table 2).

\section{Effects of intrahippocampal $c$-fos antisense ODN injection on corticosterone-induced gene expression}

$b F G F$

In CA1, $c$-fos antisense ODN increased bFGF mRNA levels (44\%) $4 \mathrm{hr}$ after CORT treatment compared with control ODN-treated rats as revealed by one-way ANOVA followed by Bonferroni's correction $\left(F_{(1,11)}=22.4\right.$, corrected $\left.p=0.0024\right)$ (Table 3, Fig. 3c,d). bFGF mRNA levels were not affected by antisense treatment 64\%; CA2: 32 to 64\%; CA3: 40 to 63\%; DG: 23 to 62\%) (Table 1, Figs. 1, 2). GR mRNA levels were not changed in vehicle-treated rats at any time point analyzed.

MR

The expression of $M R$ was significantly and time-dependently decreased by CORT in all hippocampal subregions as demonstrated by two-way ANOVA for treatment $\left(\mathrm{CA} 1: F_{(1,40)}=21.8\right.$, $p<0.0001$; CA2: $F_{(1,40)}=10.8, p=0.0021 ;$ CA3: $F_{(1,38)}=47.3$, $p<0.0001$; DG: $\left.F_{(1,38)}=42.9, p<0.0001\right)$ and interaction of treatment and time $\left(\mathrm{CA} 1: F_{(1,40)}=3.2, p=0.023\right.$; CA3: $F_{(1,38)}=$ 12.8, $p<0.0001$; DG: $\left.F_{(1,38)}=12.2, p<0.0001\right)$. Bonferroni's corrected Fisher's post hoc analysis revealed a significant decrease in MR mRNA levels after 2 and $4 \mathrm{hr}$ in CA1 (27 to 39\%) (Table 1, Figs. 1, 2), after $4 \mathrm{hr}$ in CA3 (34 to 43\%) (Table 1, Figs. 1, 2), and between 4 and $8 \mathrm{hr}$ in DG (31 to 56\%) (Table 1, Figs. 1, 2). Interestingly, there was a small and significant increase in $M R$ mRNA levels by $21 \%$ in CA3 after 50 min (Table 1, Fig. 1). In CA2, the corrected post hoc test did not show significant differences between CORT- and vehicle-treated rats (Table 1, Figs. 1, 2). Furthermore, $M R$ mRNA levels were not changed in vehicletreated rats at any time point analyzed.

c-fos

The expression of $c$-fos was time-dependently and significantly decreased after CORT treatment only in the DG as suggested by two-way ANOVA for treatment $\left(F_{(1,38)}=21.8, p<0.0001\right)$ and interaction of treatment and time $\left(F_{(1,38)}=3.3, p=0.021\right)$. The corrected post hoc test showed significant decreases of $c$-fos mRNA levels in the DG between $50 \mathrm{~min}$ and $2 \mathrm{hr}$ (38 to 46\%) (Table 1, Figs. 1, 2). There was no treatment or interaction effect in other hippocampal regions.

Furthermore, the two-way ANOVA demonstrated a strong time effect in all subregions (CA1: $F_{(1,38)}=33, p<0.0001$; CA3: $F_{(1,40)}=16.6, p<0.0001$; DG: $\left.F_{(1,38)}=16.1, p<0.0001\right)$. Corrected post hoc analysis revealed strong and significant increases in other subregions. The antisense effect was observed only at bregma levels close to the injection site.

\section{BDNF}

Blockade of $c$-fos expression enhanced the $4 \mathrm{hr}$ CORT response on BDNF in CA1 by decreasing mRNA levels to $38 \%$ versus control oligo-treated rats (one-way ANOVA: $F_{(1,7)}=32.7$, corrected $p=0.0021$ ) (Table 3, Fig. 3c,d). Other hippocampal subregions were not affected by antisense treatment. The antisense effect was observed only at bregma levels close to the injection site.

\section{GR and MR}

Intrahippocampal $c$-fos blockade did not affect the CORT response on $G R$ and $M R$ mRNA levels in any subregion (Table 3).

c-fos

Antisense $c$-fos treatment induced a strong increase of $c$-fos mRNA levels in CA1 (89\%) as shown by one-way ANOVA followed by Bonferroni's correction $\left(F_{(1,10)}=10.8\right.$, corrected $p=$ 0.0246 ) (Table 3, Fig. 3d). The increase of $c$-fos mRNA levels was observed only at bregma levels close to the injection site.

\section{Distribution of end-labeled antisense c-fos oligodeoxynucleotides}

The distribution of $\left[\mathrm{S}^{35}\right] \gamma \mathrm{ATP}$ end-labeled phosphorothioate modified antisense $c$-fos ODN after intrahippocampal injection was demonstrated by autoradiography. A high intensity labeling was found close to the injection site $1 \mathrm{hr}$ after injection (Fig. $3 b$ ). After $6 \mathrm{hr}$, weak labeling was found with the same distribution as seen after $1 \mathrm{hr}$ (data not shown).

\section{Cellular distribution of $c$-fos mRNA in the hippocampus} Double labeling of $c$-fos mRNA and GFAP immunoreactivity (-ir) demonstrates that $c$-fos is mainly located outside of GFAPimmunoreactive profiles in large and weakly cresyl violet-stained 


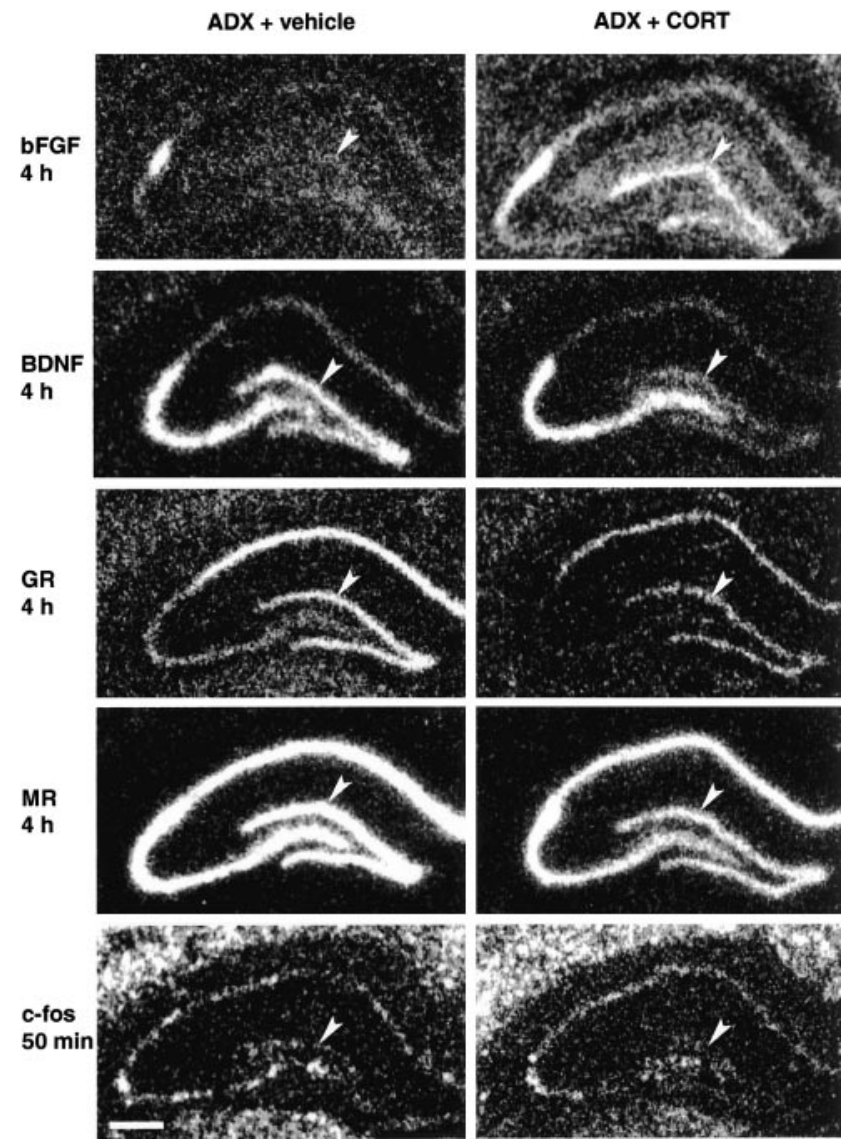

Figure 2. Dark-field microphotographs from autoradiograms of in situ hybridization of $b F G F_{\text {, }}$ $B D N F, G R$, and MR mRNA levels $4 \mathrm{hr}$ after injection and of c-fos mRNA levels $50 \mathrm{~min}$ after subcutaneous injection in ADX + vehicle-treated (left panel) and ADX + CORT-treated (10 $\mathrm{mg} / \mathrm{kg}$, right panel) rats. Arrowheads show mRNA signals in the dentate gyrus. Bregma levels were -3 to $-4 \mathrm{~mm}$. Scale bar, $1 \mathrm{~mm}$.

Table 2. Effects of injection stress on c-fos mRNA levels in the dorsal hippocampus of ADX rats

\begin{tabular}{lclll}
\hline Treatment & Time & CA1 & CA3 & DG \\
\hline ADX & $50 \mathrm{~min}$ & $74 \pm 5$ & $89 \pm 5$ & $67 \pm 1$ \\
ADX + vehicle & $50 \mathrm{~min}$ & $61 \pm 2$ & $87 \pm 7$ & $49 \pm 10^{*}$ \\
ADX & $4 \mathrm{hr}$ & $42 \pm 6$ & $41 \pm 3$ & $41 \pm 1$ \\
ADX + vehicle & $4 \mathrm{hr}$ & $45 \pm 3$ & $49 \pm 4$ & $47 \pm 4$ \\
DX & $24 \mathrm{hr}$ & $36 \pm 6$ & $43 \pm 4$ & $31 \pm 1$ \\
ADX + vehicle & $24 \mathrm{hr}$ & $41 \pm 7$ & $63 \pm 7$ & $42 \pm 4$ \\
\hline
\end{tabular}

Data are expressed as optical densities $\left(\times 10^{3}\right.$, means $\left.\pm S E M\right) ;$ n.e. $=$ not evaluated. Analysis at Bregma levels -3 to $-4 \mathrm{~mm}$ were performed by two-way ANOVA (treatment $\times$ time) followed by Fisher's PLSD test and Bonferroni's correction. Significances between mRNA levels are shown between hormone vehicle-injected ( $A D X+$ vehicle) and non-injected ADX rats at the same time point. ${ }^{*} p<0.05 ; n=4$ per group.

cell nuclei within the pyramidal cell layer of CA and the granular cell layer of DG, probably representing nerve cells. The distribution of the $c$-fos signal appears in a "speckled" pattern, i.e., a few large neurons here and there are strongly labeled above the average $c$-fos signal (Fig. 4).

Colocalization of c-fos and GR, c-fos and NeuN, and c-fos and GFAP-ir in the hippocampus

The colocalization of c-fos-ir and GR-ir and markers for neurons (NeuN-ir) and astrocytes (GFAP-ir) were studied in CA1, CA3, and DG of ADX rats $1.5 \mathrm{hr}$ after corticosterone treatment. Double immunofluorescence analysis of nuclear c-fos-ir (red color) and nuclear GR-ir or nuclear NeuN-ir (both with green color)
Table 3. Effects of $c$-fos antisense oligonucleotides on gene expression in response to corticosterone $(10 \mathrm{mg} / \mathrm{kg}$, s.c.) in the dorsal hippocampus of ADX rats

I. Analysis at Bregma levels close to the implanted cannula guide

\begin{tabular}{lllll}
\hline & CA1 & CA2 & CA3 & DG \\
\hline $\begin{array}{llll}\text { bFGF mRNA } \\
\quad \text { Control oligo }\end{array}$ & $102 \pm 7$ & $347 \pm 16$ & $99 \pm 8$ & $214 \pm 11$ \\
$\quad$ Antisense c-fos oligo & $147 \pm 7^{* *}$ & $428 \pm 28$ & $103 \pm 11$ & $229 \pm 15$ \\
BDNF mRNA & & & & \\
$\quad$ Control oligo & $29 \pm 1$ & n.e. & $108 \pm 9$ & $127 \pm 17$ \\
$\quad$ Antisense c-fos oligo & $18 \pm 1^{* *}$ & n.e. & $118 \pm 7$ & $116 \pm 15$ \\
GR mRNA & & & & \\
$\quad$ Control oligo & $238 \pm 12$ & $234 \pm 14$ & $121 \pm 6$ & $279 \pm 27$ \\
$\quad$ Antisense c-fos oligo & $303 \pm 26$ & $308 \pm 37$ & $152 \pm 9$ & $335 \pm 30$ \\
MR mRNA & & & & \\
$\quad$ Control oligo & $388 \pm 28$ & $860 \pm 41$ & $534 \pm 47$ & $473 \pm 29$ \\
$\quad$ Antisense c-fos oligo & $446 \pm 35$ & $828 \pm 49$ & $557 \pm 38$ & $544 \pm 58$ \\
c-fos mRNA & & & & \\
$\quad$ Control oligo & $53 \pm 5$ & n.e. & $78 \pm 11$ & $185 \pm 26$ \\
$\quad$ Antisense c-fos oligo & $100 \pm 13^{*}$ & n.e. & $131 \pm 16$ & $177 \pm 17$ \\
\hline
\end{tabular}

II. Analysis at Bregma levels -4 to $-4.5 \mathrm{~mm}$

\begin{tabular}{lllll}
\hline & CA1 & CA2 & CA3 & DG \\
\hline $\begin{array}{llll}\text { bFGF mRNA } \\
\quad \text { Control oligo }\end{array}$ & $107 \pm 6$ & $319 \pm 24$ & $91 \pm 7$ & $207 \pm 17$ \\
$\quad$ Antisense c-fos oligo & $129 \pm 14$ & $386 \pm 36$ & $96 \pm 10$ & $215 \pm 22$ \\
BDNF mRNA & & & & \\
$\quad$ Control oligo & $28 \pm 3$ & n.e. & $81 \pm 17$ & $108 \pm 30$ \\
$\quad$ Antisense c-fos oligo & $15 \pm 3$ & n.e. & $103 \pm 8$ & $99 \pm 23$ \\
GR mRNA & & & & \\
$\quad$ Control oligo & $300 \pm 14$ & $259 \pm 14$ & $148 \pm 7$ & $328 \pm 26$ \\
$\quad$ Antisense c-fos oligo & $269 \pm 13$ & $236 \pm 19$ & $131 \pm 13$ & $291 \pm 26$ \\
MR mRNA & & & & \\
$\quad$ Control oligo & $408 \pm 17$ & $874 \pm 43$ & $507 \pm 36$ & $483 \pm 22$ \\
$\quad$ Antisense c-fos oligo & $351 \pm 29$ & $744 \pm 66$ & $470 \pm 61$ & $463 \pm 47$ \\
c-fos mRNA & & & & \\
$\quad$ Control oligo & $62 \pm 12$ & n.e. & $80 \pm 17$ & $208 \pm 29$ \\
$\quad$ Antisense c-fos oligo & $92 \pm 15$ & n.e. & $128 \pm 23$ & $160 \pm 26$ \\
\hline
\end{tabular}

Data are expressed as optical densities $\left(\times 10^{3}\right.$, means $\left.\pm S E M\right) ;$ n.e. $=$ not evaluated. Analysis was performed by one-way ANOVA followed by Fisher's PLSD test and Bonferroni's correction. Significances between mRNA levels are shown between c-fos antisense oligodeoxynucleotides (antisense c-fos oligo) and randomized oligodeoxynucleotides (control oligo) treated animal groups for each gene analyzed; ${ }^{*} p<0.05 ;{ }^{* *} p<0.01 ; n=6$ per group.

showed a predominant colocalization (yellow color) of the relatively low number of c-fos-ir nuclei, with GR-ir and NeuN-ir nuclei found in large numbers in all analyzed regions of the hippocampus (Fig. 5). There was no colocalization of c-fos-ir and GFAP-ir in the hippocampus. Thus, c-fos-ir is found mainly in GR-ir neurons of the hippocampus; however, only a small population of the GR-ir neurons is c-fos-ir.

\section{Discussion}

The data presented here support the view that hippocampal neurotrophic factors and corticosteroid receptors are target genes for glucocorticoid regulation (Chao et al., 1989, 1998; Herman et al., 1989; Pfeiffer et al., 1991; Barbany and Persson, 1992; Chadi et al., 1993; Follesa and Mocchetti, 1993; Herman, 1993; Chao and McEwen, 1994; Riva et al., 1995; Smith et al., 1995a,b; Mocchetti et al., 1996; Schaaf et al., 1997, 1998, 2000; Hansson et al., 2000, 2001; Molteni et al., 2001). A time course for CORT revealed peak hormone responses for these genes, except for $c$-fos, at the $4 \mathrm{hr}$ time interval. Hippocampal $b F G F$ mRNA levels are strongly and positively regulated by CORT, in contrast to the negative regulation of BDNF, GR, and MR mRNA levels by CORT. $c$-fos mRNA levels are negatively regulated exclusively in the DG. Using the same ADX animal model and time intervals for hormonal peak 

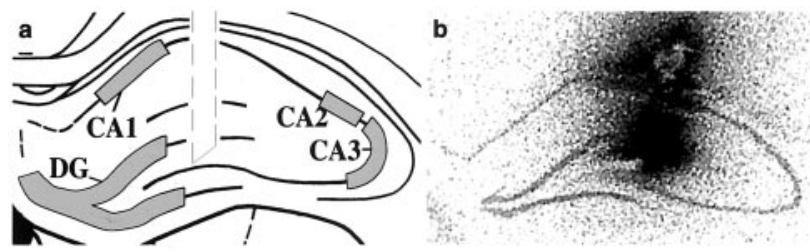

c random oligo
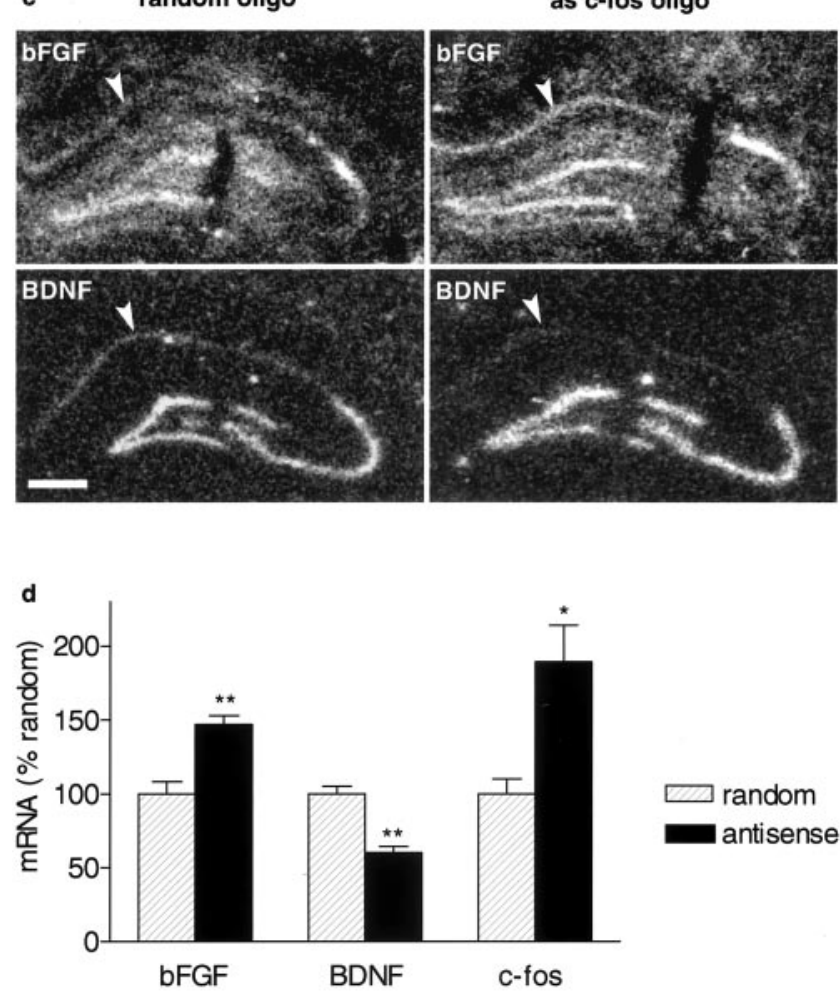

Figure 3. a, Schematic representation to show the position of the cannula guide and of the sampled areas for densitometric evaluation in a coronal section through the dorsal hippocampus (bregma level -3.3 mm). CA1-CA3, Cornus Ammon areas; DG, dentate gyrus. $b$, Distribution of ${ }^{35}$ S-end-labeled antisense $c-f o s$ ODN $1 \mathrm{hr}$ after intrahippocampal injection as shown in a cresyl violet-counterstained coronal section (bregma level $=-3$ to $-4 \mathrm{~mm}$ ). c, Dark-field microphotographs from in situ hybridization of autoradiograms of $b F G F$ and BDNF mRNA levels in response to CORT ( $10 \mathrm{mg} / \mathrm{kg}$, s.c.) after randomized (left panel) and antisense c-fos ODN (right panel) treatment. Arrowheads show mRNA signals in the CA1 region (bregma levels $=-3$ to $-4.5 \mathrm{~mm}$ ). Scale bar, $1 \mathrm{~mm}$. $d$, Densitometric evaluation of in situ hybridization autoradiograms. Values are given as percentage of random oligo-treated group (mean $\pm S E M ; n=6$ ). Statistical analysis was performed by one-way ANOVA (treatment) followed by Bonferroni's correction. ${ }^{*} p<0.05,{ }^{* *} p<0.01$ versus random oligo group. CA1, Cornus Ammon area. For details on treatment, see Materials and Methods.

response, the main finding obtained on the basis of the antisense approach was that c-fos can suppress the CORT-induced responses in bFGF and BDNF expression in CA1, demonstrating an antagonistic interaction of activated GR/MR with c-fos mechanisms in the control of these genes.

\section{Effects of corticosterone on hippocampal c-fos gene expression}

In the present paper, $c$-fos mRNA levels are significantly downregulated by CORT in the DG. Previous communications on CORT effects on $c$-fos expression reported conflicting results. In tissue cultures, glucocorticoids increased $c$-fos mRNA levels, as shown for AtT-20 pituitary tumor cells (Lin et al., 1992) and primary hypothalamic cells (Luo and Jackson, 1998), decreased c-fos mRNA levels in C6 glioma cells (Yin and Howells, 1992), or

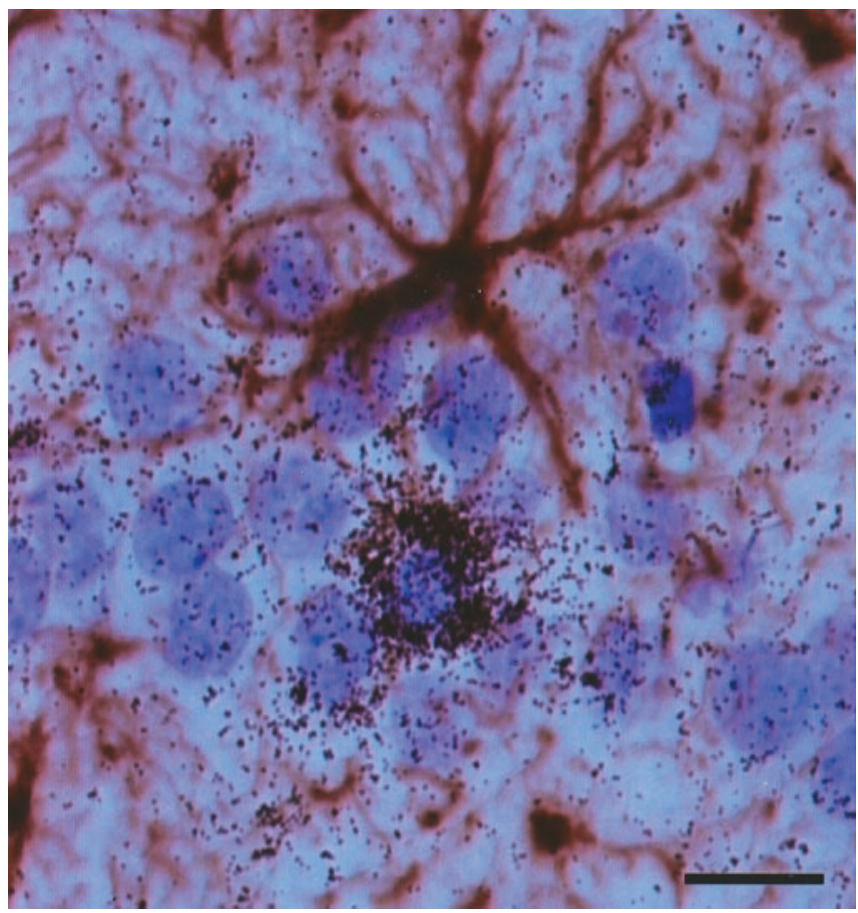

Figure 4. Bright-field photomicrographs showing a strongly labeled nerve cell enriched in silver grains, representing c-fos transcripts, and a GFAP-ir (brown color) astroglial cell lacking silver grains in the same cresyl violet counterstained section in the CA1 region of corticosteronetreated (10 mg/kg, s.c.; $4 \mathrm{hr}$ ) ADX rat. CA1, Cornus Ammon area. For details on treatment, see Materials and Methods. Scale bar, $15 \mu \mathrm{m}$. Bregma level $=-3$ to $-4.5 \mathrm{~mm}$.

had no effect in AtT-20 cells (Autelitano, 1994). Chronic treatment with the synthetic glucocorticoid dexamethasone inhibits stress-induced $c$-fos expression in the hypothalamic paraventricular nucleus (Kovács and Sawchenko, 1996), which is in line with the present results.

Normally, basal $c$-fos levels in naive animals are low (Herdegen and Leah, 1998). Here, significantly increased $c$-fos mRNA levels in all experimental groups were observed at the $50 \mathrm{~min}$ time point compared with the other time points. Handling of the animals (Asanuma et al., 1992) or the novel environment (Wirtshafter et al., 1998), or both, may be involved in the initial induction of $c$-fos mRNA levels reported in the present paper, and in fact the impact of such effects for hippocampal $c$-fos expression has been reported previously (Kovács, 1998). Except for the DG, the present $c$-fos induction neither seems to be dependent on circulating glucocorticoids (hormone- vs vehicle-injected ADX rats) nor does it appear to be associated with the injection stress (non-injected vs vehicle-injected ADX rats). A dissociation of c-fos upregulation from the hormonal stress response was also found by others (Melia et al., 1994; Helmreich et al., 1996; Ryabinin et al., 1999). In DG the injection procedure by itself appears to reduce $c$-fos levels. The opposing effect on $c$-fos expression by novelty and pain stimuli may be a result of different pathways involved in their mediation. These effects, however, can clearly be separated from the CORT effect. Furthermore, the expression of neurotrophic factor and corticosteroid receptor mRNA levels shows a stable baseline over time in control rats. Their CORTinduced gene regulation therefore may not be confounded by the initial rise in $c$-fos $\mathrm{mRNA}$ levels.

As stated above, CORT seems to counteract the initial increase of $c$-fos expression in the DG. The mechanism involved may be that activated GR/MR can suppress $c$-fos transcription via bind- 
ing to a putative GRE in the promoter region (Wang and Howells, 1994) or that activated GR/MR can interact with Jun/Fos heterodimers leading to reduced AP-1 activity (Teurich and Angel, 1995).

\section{Effects of antisense blockade of $c$-fos on gene expression}

Inducible transcription factors may not only interact directly with DNA but may also indirectly modify transcription processes by complexing with other transcriptionally operating proteins. Therefore the second experiment tested whether AP-1, i.e. c-fos, is involved in the CORT regulation of genes by use of intrahippocampal antisense "knockdown" of $c$-fos expression. Antisense treatment increased $b F G F$ and decreased BDNF mRNA levels after CORT administration, and hence an enhancement of the CORTinduced transcriptional regulation of these genes was found. The CA1 area contains fewer $b F G F$ and BDNF mRNA signals than the $\mathrm{CA} 3$ or the $\mathrm{DG}$, and the magnitude of changes induced by the antisense treatment was modest using semiquantitative measurements. Nevertheless, such a change in a modest signal may have consequences for the relatively low signaling at the receptors for these neurotrophic factors in CA1, because the corresponding changes in the proteins may be at least as large. An inhibitory effect of $c$-fos on gene regulation by glucocorticoids has earlier been described in tissue culture studies by Diamond et al. (1990), Jonat et al. (1990), Lucibello et al. (1990), and Pearce and Yamamoto (1993), but to our knowledge this is the first demonstration that this effect is also present in vivo. $c$-fos antisense treatment did not affect the autoregulation of $G R$ and MR by CORT. This is in line with recent findings that in NIH3T3 cells c-fos under basal, low-level conditions is not the limiting step for c-jun-mediated GR promoter repression (Cabral et al., 2001). In contrast, c-fos overexpression seems to enhance GR promoter activity (Wei and Vedeckis, 1997). The findings that c-fos/c-jun heterodimers but not c-jun homodimers bind to the AP-1-like site in the GR promoter emphasize the complexity of GR promoter regulation even further (Cabral et al., 2001).

The injection of ODNs into various regions of the brain has been used in a large number of studies to investigate the role of $c$-fos in the regulation of downstream genes or in behavioral or physiological responses associated with the activation of c-fos (for review, see Szklarczyk and Kaczmarek, 1999). For example, a number of papers have demonstrated that infusions of $c$-fos antisense ODNs into the striatum can suppress central stimulantinduced motor behavior and the associated expression of $c$-fos (Dragunow et al., 1993; Heilig et al., 1993; Sommer et al., 1993). Antisense blockade of $c$-fos in the hippocampus attenuated excitatory amino acid neurotoxicity (Lu et al., 1997) and seizureinduced heat shock protein hsp70 expression (Baille et al., 1997) and demonstrated a role of $\mathrm{c}$-fos in learning and memory (Grimm et al., 1997; Tischmeyer and Grimm, 1999).

Along with these and other studies, the $c$-fos antisense approach has been validated by various control experiments to demonstrate specificity and to establish the pharmacokinetics (Szklarczyk and Kaczmarek, 1999). For antisense ODNs targeted around the translational start site of the $c$-fos mRNA (used also in the present study), efficacy and specificity have been demonstrated at the level of translation (reduction of $c$-fos protein between 70 and 90\%) (Sommer et al., 1993; Grimm et al., 1997; Hebb and Robertson, 1997a,b; Lu et al., 1997; Lofti and Armelin,
1998; Zhang et al., 1999) and in the reduction of AP-1 complexes (Liu et al., 1994; Xu et al., 2001). Furthermore, the pharmacokinetics of $c$-fos antisense ODN in the brain has been analyzed systematically (Hebb and Robertson, 1997a,b; Grzanna et al., 1998; Sommer et al., 1998). The optimal period of antisense efficacy varied between 1 and $10 \mathrm{hr}$, depending on the degree of phosphorothioate substitution (for end-capped and fully phosphorothioated ODN, respectively) (Sommer et al., 2000). Neuronal uptake and activity for the partially phosphorothioated ODN used in the present study was found from $90 \mathrm{~min}$ to $>4 \mathrm{hr}$ (Sommer et al., 1996, 1998), giving support for the antisense action observed under the present conditions, that is, $6 \mathrm{hr}$ after the administration of the antisense $c$-fos ODN and $4 \mathrm{hr}$ after the CORT challenge. It should be noted that the antisense action studied close to the damaged area was always compared with the action of control ODNs in the same region to exclude unspecific actions.

In addition to the antisense effects on $b F G F$ and BDNF expression in the CA1 region, a strong upregulation was also found of the $c$-fos transcript itself in this region. Interestingly, in previous studies increased levels of $c$-fos mRNA was observed after intrastriatal $c$-fos antisense treatment (Sommer et al., 1996). These findings are not unexpected in light of the strong feedback regulation of $c$-fos transcription via AP-1 (Sassone-Corsi et al., 1988; Schonthal et al., 1989).

Both the regulation of $c$-fos target genes (i.e., bFGF, BDNF) and the $c$-fos autoregulation appear to be region specific, because in the present study it is observed only in the CA1 region but not in the adjacent DG, although the ODN can be found in both regions (Fig. $3 b$ ). The absence of an antisense effect in the DG may be explained by the fact that CORT is already suppressing $c$-fos expression in this region in contrast to CA1.

To demonstrate anatomic specificity of the intrahippocampally injected ODNs, we used radiolabeled partially phosphorothioated ODNs that have been found to remain intact in brain tissue up to $24 \mathrm{hr}$ after injection (Sommer et al., 2000). The distribution of these ODNs was restricted to the vicinity of the injection site and appears to match the observed antisense activity. Similarly, others reported that intrahippocampally injected ODNs do not spread outside of the hippocampus and remain within $\sim 1 \mathrm{~mm}^{3}$ of the injected area (Baille et al., 1997; Grimm et al., 1997).

Despite the demonstrated antagonistic functional interaction between GR and c-fos, only a small subpopulation of neurons within the pyramidal cell layer of the CA1 region is c-fos-ir; the majority of these nerve cells are also GR-ir. No c-fos-ir is found in astroglial cells, demonstrating a major involvement of neuronal 
cells. Nevertheless, it seems possible that the actions of the antisense $c$-fos treatment on $b F G F$ and BDNF gene expression found in large numbers of nerve and glial cells all over the CA1 area could be related to an antagonistic interaction between GR and c-fos in this small population of nerve cells. Thus, this antagonistic interaction at the promoter regions of such genes and others in this special group of cells could lead to a marked alteration in their neuronal activity, whether representing glutamate or GABA neurons, which may initiate a cascade of events leading to an altered control of the majority of BDNF nerve cells and bFGF glial cells in this region, involving recurrent collaterals and widespread terminal networks. In this way it becomes possible to understand how a potential interaction of GR and c-fos in a small group of neurons could lead to the demonstrated GR-enhancing actions of antisense $c$-fos treatment on BDNF and bFGF expression in neuronal and glial networks, respectively, the majority of which exhibit no c-fos-ir but only GR-ir. Thus, the response of these cells to GR activation with regard to BDNF and $b F G F$ expression becomes altered in view of their altered afferent input, triggered by the altered antagonistic interactions of GR and c-fos on the antisense treatment in this small population of nerve cells found mainly in the CA1 pyramidal cell layer. It must be noted, however, that in the damaged area not analyzed for c-fos-ir, c-fos-ir could exist in cells not containing GR-ir. Therefore, actions of antisense c-fos treatment may exist that occur independently of GREs.

In summary, the time course for CORT in the ADX rat revealed a peak hormone effect on neurotrophic factors ( $b F G F$, $B D N F)$ and corticosteroid receptor (GR and $M R)$ mRNA levels at the $4 \mathrm{hr}$ time interval. $c$-fos mRNA levels were negatively regulated in the dentate gyrus at the $50 \mathrm{~min}$ to $2 \mathrm{hr}$ time interval. The major finding was that local antisense $c$-fos ODN treatment significantly and selectively enhanced the CORT action only in the CA1 region on the expression of $\mathrm{bFGF}$ and BDNF mRNA versus randomized control ODN treatment. Thus, it seems as if within the CA1 area a tonic $c$-fos mechanism exists that reduces GR- or MR-induced effects, or both, on gene expression of $b F G F$ and $B D N F$.

\section{References}

Asanuma M, Ogawa N, Hirata H, Chou H, Tanaka K, Mori A (1992) Opposite effects of rough and gentle handling with repeated saline administration on $c$-fos mRNA expression in the rat brain. J Neural Transm 90:163-169.

Autelitano DJ (1994) Glucocorticoid regulation of $c$-fos, c-jun and transcription factor AP-1 in the AtT-20 corticotrope cell. J Neuroendocrinol 6:627-637.

Baille V, Lallement G, Carpentier P, Foquin A, Pernot-Marino I, Rondouin G (1997) C-fos antisense oligonucleotide prevents delayed induction of hsp70 mRNA after soman-induced seizures. NeuroReport 8:1819-1822.

Barbany G, Persson H (1992) Regulation of neurotrophin mRNA expression in the rat brain by glucocorticoids. Eur J Neurosci 4:396-403.

Beato M, Herrlich P, Schütz G (1995) Steroid hormones receptors: many actors in search of a plot. Cell 83:851-857.

Benfenati F, Cimino M, Agnati L, Fuxe K (1986) Quantitative autoradiography of central neurotransmitter receptors: methodological and statistical aspects with special aspects with special references to computerassisted image analysis. Acta Physiol Scand 128:129-146.

Cabral ALB, Hays AN, Housley PR, Brentani MM, Martins VR (2001) Repression of glucocorticoid receptor gene transcription by c-Jun. Mol Cell Endocrinol 175:67-79.

Chadi G, Rosén L, Cintra A, Tinner B, Zoli M, Pettersson R, Fuxe K (1993) Corticosterone increases FGF-2 (bFGF) immunoreactivity in the substantia nigra of the rat. NeuroReport 4:783-786.

Chao HM, McEwen BS (1994) Glucocorticoids and the expression of $\mathrm{mR}$ NAs for neurotrophins, their receptors and GAP-43 in the rat hippocampus. Brain Res Mol Brain Res 26:271-276.
Chao HM, Choo PH, McEwen BS (1989) Glucocorticoid and mineralocorticoid receptor mRNA expression in rat brain. Neuroendocrinology 50:365-371

Chao HM, Sakai RR, Ma LY, McEwen BS (1998) Adrenal steroid regulation of neurotrophic factor expression in the rat hippocampus. Endocrinology 139:3112-3118.

Diamond MI, Miner JN, Yoshinaga SK, Yamamoto KR (1990) Transcription factor interactions: selectors of positive or negative regulation from a single DNA element. Science 249:1266-1272.

Dragunow M, Lawlor P, Chiasson B, Robertson H (1993) C-fos antisense generates apomorphine and amphetamine-induced rotation. NeuroReport 5:305-306.

Follesa P, Mocchetti I (1993) Regulation of basic fibroblast growth factor and nerve growth factor mRNA by $\beta$-adrenergic receptor activation and adrenal steroids in rat central nervous system. Mol Pharmacol 43:132-138.

Funder JW (1993) Mineralocorticoids, glucocorticoids, receptors and response elements. Science 259:1132-1133.

Grimm R, Schicknick H, Riede I, Gundelfinger ED, Herdegen T, Zuschratter W, Tischmeyer W (1997) Suppression of $c$-fos induction in rat brain impairs retention of a brightness discrimination reaction. Learn Memory 3:402-413.

Grzanna R, Dubin JR, Dent GW, Ji Z, Zhang W, Ho SP, Hartig PR (1998) Intrastriatal and intraventricular injections of oligodeoxynucleotides in the rat brain: tissue penetration, intracellular distribution and $c$-fos antisense effects. Brain Res Mol Brain Res 63:35-52.

Hansson AC, Cintra A, Belluardo N, Sommer W, Bhatnagar M, Bader M, Ganten D, Fuxe K (2000) Gluco- and mineralocorticoid receptormediated regulation of neurotrophic factor gene expression in the dorsal hippocampus and the neocortex of the rat. Eur J Neurosci 12:2918-2934.

Hansson AC, Sommer W, Andbjer B, Bader M, Ganten D, Fuxe K (2001) Induction of hippocampal glial cells expressing basic fibroblast growth factor RNA by corticosterone. NeuroReport 12:141-145.

Hebb MO, Robertson HA (1997a) End-capped antisense oligodeoxynucleotides effectively inhibit gene expression in vivo and offer a low-toxicity alternative to fully modified phosphorothioate oligodeoxynucleotides. Brain Res Mol Brain Res 47:223-228.

Hebb MO, Robertson HA (1997b) Coordinate suppression of striatal ngfi-a and $c$-fos produces locomotor asymmetry and up-regulation of IEGs in the globus pallidus. Brain Res Mol Brain Res 48:97-106.

Heilig M, Engel JA, Söderpalm B (1993) C-fos antisense in the nucleus accumbens blocks the locomotor stimulant action of cocaine. Eur J Pharmacol 236:339-340.

Helmreich DL, Cullinan WE, Watson SJ (1996) The effects of adrenalectomy on stress-induced $c$-fos mRNA expression in the rat brain. Brain Res 706:137-144.

Herdegen T, Leah JD (1998) Inducible and constitutive transcription factors in the mammalian nervous system: control of gene expression by jun, fos and knox, and CREB/ATF protein. Brain Res Rev 28:370-490.

Herman JP (1993) Regulation of adrenocorticosteroid receptor mRNA expression in the central nervous system. Cell Mol Neurobiol 13:349-372.

Herman JP, Patel PD, Akil H, Watson SJ (1989) Localization and regulation of glucocorticoid and mineralocorticoid receptor messenger RNAs in the hippocampal formation of the rat. Mol Endocrinol 3:1886-1894.

Jonat C, Rahmsdorf HJ, Park KK, Cato ACB, Gebel S, Ponta H, Herrlich P (1990) Antitumor promotion and anti-inflammation: down-modulation of AP-1 (fos/jun) activity by glucocorticoids. Cell 62:1189-1204.

König H, Ponta H, Rahmsdorf HJ, Herrlich P (1992) Interference between pathway-specific transcription factors: glucocorticoids antagonize phorbol ester-induced AP-1 activity without altering AP-1 site occupation in vivo. EMBO J 11:2241-2246.

Kovács KJ (1998) c-Fos as a transcription factor: a stressful (re)view from a functional map. Neurochem Int 33:287-297.

Kovács KJ, Sawchenko PE (1996) Regulation of stress-induced transcriptional changes in the hypothalamic neurosecretory neurons. J Mol Neurosci 7:125-133.

Lin S-H, MacLeod, Hardin JW (1992) Effects of glucocorticoids on expression of the fos protooncogene in AtT-20 cells. Endocrinology 130:257-262.

Liu PK, Salminen A, He YY, Jiang MH, Xue JJ, Liu JS, Hsu CY (1994) Suppression of ischemia-induced fos expression and AP-1 activity by an antisense oligodeoxynucleotide to $c$-fos mRNA. Ann Neurol 36:566-576. 
Lofti CF, Armelin HA (1998) C-fos protein is a mediator in mitogenic response to ACTH. Endocr Res 24:421-424.

Lu XC, Tortella FC, Ved HS, Garcia GE, Dave JR (1997) Neuroprotective role of $c$-fos antisense oligonucleotide: in vitro and in vivo studies. NeuroReport 8:2925-2929.

Lucibello FC, Slater EP, Jooss KU, Beato M, Müller R (1990) Mutual transrepression of fos and the glucocorticoid receptor: involvement of a functional domain in fos which is absent in fosB. EMBO J 9:2827-2834.

Luo L-G, Jackson IMD (1998) Glucocorticoids stimulate TRH and c-fos/c-jun gene co-expression in cultured hypothalamic neurons. Brain Res 791:56-62.

Melia KR, Ryabinin AE, Schroeder R, Bloom FE, Wilson MC (1994) Induction and habituation of immediate early gene expression in rat brain by acute and repeated restraint stress. J Neurosci 14:5929-5938.

Mocchetti I, Spiga G, Hayes V, Isackson P, Colangelo A (1996) Glucocorticoids differentially increase nerve growth factor and basic fibroblast growth factor expression in the rat brain. J Neurosci 16:2141-2148.

Molteni R, Fumagalli F, Magnaghi V, Roceri M, Gennarelli M, Racagni G, Melcangi RC, Riva MA (2001) Modulation of fibroblast growth factor-2 by stress and corticosteroids: from developmental events to adult brain plasticity. Brain Res Rev 37:249-258.

Okret S, Wikström AC, Wrange O, Andersson B, Gustafsson J-Å (1984) Monoclonal antibodies against the rat liver glucocorticoid receptor. Proc Natl Acad Sci USA 81:1609-1613.

Paxinos G, Watson C (1986) The rat brain in stereotaxic coordinates. San Diego: Academic.

Pearce D (1994) A mechanistic basis for distinct mineralocorticoid and glucocorticoid receptor transcriptional specificities. Steroids 59:153-159.

Pearce D, Yamamoto K (1993) Mineralocorticoid and glucocorticoid receptor activities distinguished by nonreceptor factors at a composite response element. Science 259:1161-1165.

Pfeiffer A, Lapointe B, Barden N (1991) Hormonal regulation of type II glucocorticoid receptor messenger ribonucleic acid in rat brain. Endocrinology 129:2166-2174.

Reichardt HM, Kaestner KH, Tuckermann J, Kretz O, Wessely O, Bock R, Gass P, Schmidt W, Herrlich P, Angel P, Schütz G (1998) DNA binding of the glucocorticoid receptor is not essential for survival. Cell 93:531-541.

Riva M, Fumagalli F, Racagni G (1995) Opposite regulation of basic fibroblast growth factor and nerve growth factor gene expression in rat cortical astrocytes following dexamethasone treatment. J Neurochem 64:2526-2533.

Ryabinin AE, Wang Y-M, Finn DA (1999) Different levels of fos immunoreactivity after repeated handling and injection stress in two inbred strains of mice. Pharmacol Biochem Behav 63:143-151.

Sassone-Corsi P, Sisson JC, Verma IM (1988) Transcriptional autoregulation of the proto-oncogene fos. Nature 334:314-319.

Schaaf MJM, Hoetelmans RWM, de Kloet ER, Vreugdenhil E (1997) Corticosterone regulates expression of BDNF and trkB, but not NT-3 and trkC mRNA in the hippocampus. J Neurosci Res 48:334-341.

Schaaf MJM, de Jong J, de Kloet ER, Vreugdenhil E (1998) Downregulation of BDNF mRNA and protein in the rat hippocampus by corticosterone. Brain Res 813:112-120.

Schaaf MJM, de Kloet ER, Vreugdenhil E (2000) Corticosterone effects on BDNF expression in the hippocampus. Implications for memory formation. Stress 3:201-208.

Schonthal A, Buscher M, Angel P, Rahmsdorf HJ, Ponta H, Hattori K, Chiu, Karin M, Herrlich P (1989) The fos and jun/AP-1 proteins are involved in the downregulation of fos transcription. Oncogene 4:629-636.
Schüle R, Rangarajan P, Kliewer S, Ransone LJ, Bolado J, Yang N, Verma IM, Evans RM (1990) Functional antagonism between oncoprotein c-jun and the glucocorticoid receptor. Cell 62:1217-1226.

Smith M, Makino S, Kvetnansky R, Post RM (1995a) Effects of stress on neurotrophic factor expression in the rat brain. Ann NY Acad Sci 771:234-239.

Smith M, Makino S, Kvetnansky R, Post RM (1995b) Stress and glucocorticoids affect the expression of brain-derived neurotrophin and neurotrophin-3 mRNAs in the hippocampus. J Neurosci 15:1768-1777.

Sommer W, Bjelke B, Ganten D, Fuxe K (1993) Antisense oligonucleotide to $c$-fos induces ipsilateral rotational behaviour to d-amphetamine. NeuroReport 5:277-280.

Sommer W, Rimondini R, O'Connor W, Hansson AC, Ungerstedt U, Fuxe K (1996) Intrastriatally injected $c$-fos antisense oligonucleotide interferes with striatonigral but not striatopallidal $\gamma$-aminobutyric acid transmission in the conscious rat. Proc Natl Acad Sci USA 93:14134-14139.

Sommer W, Cui X, Erdmann B, Wiklund L, Bricca G, Heilig M, Fuxe K (1998) The spread and uptake pattern of intracerebrally administered oligonucleotides in nerve and glial cell populations of the rat brain. Antisense Nucleic Acid Drug Dev 8:75-85.

Sommer W, Hebb MO, Heilig M (2000) Pharmacokinetic properties of oligonucleotides in brain. Methods Enzymol 314:261-275.

Szklarczyk AW, Kaczmarek L (1999) Brain as a unique antisense environment. Antisense Nucleic Acid Drug Dev 9:105-116.

Teurich S, Angel P (1995) The glucocorticoid receptor synergizes with jun homodimers to activate AP-1 regulated promoters lacking GR binding sites. Chem Senses 20:251-255.

Tischmeyer W, Grimm R (1999) Activation of immediate early genes and memory formation. Cell Mol Life Sci 55:564-574.

Wang WW, Howells RD (1994) Sequence of the 5 '-flanking region of the rat c-fos proto-oncogene. Gene 143:261-264.

Wei P, Vedeckis WV (1997) Regulation of the glucocorticoid receptor gene by the AP-1 transcription factor. Endocrine 7:303-310.

Wirtshafter D, Stratford TR, Shim I (1998) Placement in a novel environment induces fos-like immunoreactivity in supramammillary cells projecting to the hippocampus and midbrain. Brain Res 789:331-334.

Xu J, Kim GM, Ahmed SH, Yan P, Xu XM, Hasu CY (2001) Glucocorticoid receptor-mediated suppression of activator protein-1 activation and matrix metalloproteinase expression after spinal cord injury. J Neurosci 21:92-97.

Yang-Yen HF, Chambard JC, Sun YL, Smeal T, Schmidt TJ, Drouin J, Karin M (1990) Transcriptional interference between cJun and the glucocorticoid receptor: mutual inhibition of DNA-binding due to direct proteinprotein interaction. Cell 62:1205-1215.

Yin J, Howells RD (1992) Glucocorticoid-mediated down regulation of $c$-fos mRNA in C6 glioma cells: Lack of correlation with proenkephalin mRNA. Brain Res Mol Brain Res 12:187-194.

Zhang T, Widmayer MA, Zhang B, Cui JK, Baskin DS (1999) Suppression of post-ischemic-induced fos protein expression by antisense oligonucleotide to $c$-fos mRNA leads to increased tissue damage. Brain Res 832:112-117.

Zoli M, Bettuzzi S, Ferraguti F, Ingletti M, Zini I, Fuxe K, Agnati L, Corti A (1991) Regional increases in ornithine decarboxylase mRNA levels in the rat brain after partial mesodiencephalic hemitransection as revealed by in situ hybridization histochemistry. Neurochem Int 18:347-352. 